\title{
Ultrastructure and Histochemistry of the Submandibular Gland of the Japanese Wood Mouse (Apodemus ainu ainu TOKUDA)
}

\author{
Mikiyo Odajima \\ Department of Oral Anatomy (Prof. F. NAKANE), Hokkaido University School of Dentistry, Sapporo, \\ Japan
}

Received December 1, 1980

\begin{abstract}
Summary. The submandibular glands of adult female and male Japanese wood mice (Apodemus ainu ainu ToKUDA) were studied histochemically using toluidine blue (pH 2.5, 4.1 and 7.0, McIlvaine), PAS reaction, Millon's reaction for tyrosine, p-dimethylaminobenzaldehyde for tryptophan, and substrate film techniques for amylase and protease. The glands were also examined ultrastructurally and ultracytochemically by the periodic acid-thiocarbohydrazide-silver proteinate technique (PA-TCH-SP staining) for glycoprotein. The submandibular gland consisted of the striated ducts (SDs), the convoluted granular tubules (CGTs), the intercalated ducts and the terminal portions. In both sexes the acinar cells were seromucous in secretory nature, and the secretory granules contained glycoproteins and were negative to amylase and protease activities. By the PA-TCHSP staining, the distribution of glycoproteins and fine structural alternations corresponding to the maturation of the secretory granules were demonstrated. The granules of the CGT cells contained tryptophan, tyrosine and neutral mucopolysaccharides. The granules showed negative reactions to acid mucopolysaccharides, protease and amylase activities, and glycoproteins. Glycogen particles in the apocrine processes were intensely positive to PA-TCH-SP staining. Dark and clear cells were distinguished in the SDs. The apical cytoplasm of the SD cells contained two types of vesicles. One type may represent reabsorption vesicles and the other secretory vesicles. Some of the SD cells had both microvilli, associated with reabsorption vesicles and apocrine process containing abundant glycogen particles on their luminal surface. From the statistical analysis of the average values, the CGT diameter of the male mice was significantly larger than that of the female mice.
\end{abstract}

The submandibular glands of most rodents consists of acini, intercalated ducts, convoluted granular tubules (CGTs), striated ducts (SDs) and interlobular excretory ducts. The acinar cells synthesize and secrete glycoproteins, and the ducts, which convey them to the oral cavity, modify the proteins during their passage.

The CGT of the submandibular gland in rodents has long attracted the attention of researchers because of their hormone dependent granules. Sexual dimorphism of 
the CGT has been recognized in hamster salivary glands demonstrated by histochemistry (KRONMAN, 1963a, b) and from histometric observations in rats (MUdD and White, 1975) and mice (FuKudA, 1973). It has been reported, from measurements of the diameter of CGTs in the two heteromyid subfamilies (FLON et al., 1970), that the diversity and variations in the CGTs in rodents may be attributed to inherent species differences. It has been proposed by MATERAzzi and Vitaioli (1969) that the secretions of rat CGTs act as a pheromone, whereas in the mouse an ability of CGTs to concentrate iodine from the serum has been reported (BROWN-GRANT and TAYLOR, 1963). For many years the CGTs have attracted the interest of many investigators because of their sensitivity to hormones (LAcAssagne, 1940; Shafer and Muhler, 1953; Sreebny and Meyer, 1964; Kronman and Chaucey, 1964, 1965; Kronman and SPINALE, 1965; LiU and Lin, 1969). It has recently been suggested that the salivary gland might be concerned with diabetes (Hoshino et al., 1976; LAwrence et al., 1977; KIM et al., 1979). The functional significance of the CGTs in the submandibular gland, however, has not yet been clarified.

SD cells generally have highly developed basal infoldings and a number of mitochondria arranged parallel to the infolded membranes (ScotT and Pearse, 1959; Parks, 1961; Rutberg, 1961; TANDler, 1963; TAmarin and Sreebny, 1965; IchiKawa and ICHIKAWA, 1975; OdAJIMA, 1980), similar structures were observed in the renal proximal tubules, choroid plexus and ciliary body. Physiological studies have demonstrated that the SDs transport ions and electrolytes (IMAI and Yoshimura, 1972; Kaladelfos and Young, 1974; Schneyer et al., 1972). Small vesicles containing material of moderate density have been observed in the apical cytoplasm of SD cells in different species and these have been considered to be secretory granules by PARKS (1961), Garrett and KIdD (1975) and Hand (1979). On the other hand, RutberG (1961), Tamarin and Sreebny (1965), Schackleford and Wilborn (1970), Riva et al. (1976), and TESTA-Riva (1977) have suggested that these vesicles are involved in a reabsorption activity of the SD cells, based on their findings that the vesicle formation around the Golgi apparatus and the discharge of these granules were not observed in these cells.

This study was undertaken to study the functional characteristics and the ultrastructure of the submandibular gland of the Japanese wood mouse Apodemus ainu ainu ToKUDA, with special references on the acinar cells, CGT cells, and SD cells, and also on the sexual dimorphism of CGTs in this animal.

\section{MATERIALS AND METHODS}

Nineteen male and 11 female adult Japanese wood mice $(A$. $a$. ainu) were captured in a forest on Mt. Moiwa, Hokkaido in October and November; they were killed shortly thereafter.

The submandibular glands from 1 female and 4 male mice were fixed in buffered $10 \%$ formalin for $6 \mathrm{hr}$ and processed for paraffin sectioning. Sections $(5-6 \mu \mathrm{m})$ were cut serially and stained with the Millon's reaction for tyrosine, the p-dimethylaminobenzaldehyde method for tryptophan, 0.05\% toluidine blue (McIlvaine, $\mathrm{pH}$ 2.5, 4.1 and 7.0) for acid mucopolysaccharides, or the PAS reaction for neutral mucopolysaccharides. 
After killing 4 male mice by striking them on the head, the submandibular glands were removed and immediately frozen in isopentane cooled by liquid nitrogen. Sections were cut on a cryostat and then incubated for 15, 30,60 min, and $24 \mathrm{hr}$ at $37^{\circ} \mathrm{C}$ in humidified atmosphere according to the starch substrate method for amylase (SheAR and PEARSE, 1963) or the gelatin substrate film method for protease (SHEAR, 1972).

For the ultrastructural investigations, small tissue blocks were dissected from the submandibular glands of 10 female and 11 male mice, and they were fixed with continuous shaking in a cold 50\% Karnovsky fixative ( $\mathrm{pH} 7.4$, phosphate buffer) for $3 \mathrm{hr}$ or in a cold $5 \%$ formalin ( $\mathrm{pH} \mathrm{7.4,} \mathrm{phosphate} \mathrm{buffer)} \mathrm{for} 3 \mathrm{hr}$. The blocks were rinsed and shaken in the phosphate buffer for 6-12 hr, and half of the blocks were dehydrated with ethanol, and embedded in Epon. The other half of the blocks were postfixed in a cold $1 \% \mathrm{OsO}_{4}$ solution ( $\mathrm{pH} 7.4$, phosphate buffer), dehydrated, and embedded in Epon. Ultrathin sections were cut on a LKB 8800 ultramicrotome and observed under a Hitachi HU-11DS electron microscope.

To determine the existence of glycoprotein, the PA-TCH-SP staining method by THIÉRY (1967) was used for the ultrathin sections. The periodate oxydizing treatment was omitted for the control sections.

For the examination of sex differences, every sixth $1 \mu \mathrm{m}$-thick serial section was stained with toluidine blue, the diameter of the 50 CGTs was measured by a micrometer under a light microscope, and the average values and the standard deviations were calculated.

\section{RESULTS}

\section{Light microscopy}

The submandibular gland of Japanese wood mice was found to be a compound tubuloacinar gland and its duct system consisted of an excretory duct, the SD, the CGT and an intercalated duct. The intercalated duct next to the CGT branched into two or three ducts and led to the terminal portions. The secretory granules of the acinar cells were faintly positive to tryptophan and tyrosine, positive to the methachromasia by $0.05 \%$ toluidine blue (McIlvaine) at $\mathrm{pH} 4.1$ and 7.0, and again positive to PAS (Table 1). These results show that the granules of the acinar cells contained a small amount of protein, acid mucopolysaccharides and neutral mucopolysaccharides, and the acinar cells can be classified as seromucous cells. Both amylase and protease activities were negative in the acinar cells.

The granules of the CGT cells were intensely positive to tryptophan and tyrosine. They were negative to toluidine blue metachromasia at $\mathrm{pH}$ values $2.5,4.1$ and 7.0. They were PAS-positive, while both the amylase and protease activities were negative (Table 1). It is clear, therefore, that the granules of the CGT cells contained neutral mucopolysaccharides and protein.

\section{Electron microscopy}

The acinar cells contained well developed lamellae of rough surface endoplasmic reticulum surrounding the basally located nucleus, Golgi apparatuses above the nucleus, and a number of secretory granules dispersed throughout the lateral side of the 
Table. 1. Staining reactions of the acinar cells and the convoluted granular tubule cells in the submandibular gland of Japanese wood mouse

\begin{tabular}{clcc}
\hline & & $\begin{array}{c}\text { Acinar } \\
\text { cells }\end{array}$ & $\begin{array}{c}\text { Convoluted } \\
\text { granular } \\
\text { tubules }\end{array}$ \\
\hline L. M. & PAS & + & + \\
& Tryptophan & \pm & + \\
& Tyrosine & \pm & + \\
& Toluidine blue metachromasia & & \\
& pH 2.5 & - & - \\
& pH 4.1 & \pm & - \\
& pH 7.0 & \pm & - \\
& Amylase & - & - \\
& Protease & - & - \\
\hline E. M. & Glycoprotein & + & - \\
\hline
\end{tabular}

L. M.: light microscopy, E. M.: electron microscopy

nucleus to the apical region of the cells (Fig. 1,2), indicating a high secretory activity in the cells. Laterally, adjacent cells were loosely interdigitated with lamellar cytoplasmic processes. There were well-developed intercellular canaliculi with a wide lumen. Secretory granules discharged from the acinar cells were often found in the intercellular canaliculi (Fig. 1). In the basal region of the cell, there were also cell processes interdigitating with others. A flat basal lamina was present close to the basal surface of the acinar cells. It was not infolded into the spaces between the cell processes (Fig. 2). The secretory granules of the acinar cells were spheroid in shape, and many of them showed internal substructures (Fig. 1, 5-8). The content of these granules varied considerably in electron density from high to low in different granules. Flocculent material of low electron density was recognized in some granules (Fig. 1, 3, 4). The granules tended to fuse together. Where the fusion occurred between the granules with high and low electron-dense contents, the former was incorporated into the latter, granules decreasing in size and becoming lower in density (Fig. 3,4). The contents of the fused granules were finally discharged into the lumen of the acinus or the intercellular canaliculi (Fig. 1). Granules with electrondense contents were observed around the Golgi apparatus. Their contents were

Fig. 1. An electronmicrograph of acinar cells of the submandibular gland in Apodemus ainu ainu. The contents of the secretory granules $(G R)$ of the acinar cells vary in electron density. Intercellular canaliculi $(I C)$ are well-developed. Secretory granules are discharged into the intercellular canaliculus (arrowhead). $\times 7,410$

Fig. 2. Basal region of an acinus showing interdigitating cell processes (arrowhead). $\times 7,500$

Fig. 3. Fusion of the granules with contents of high and low electron density seen in an acinar cell. The electron-dense contents have been absorbed into the less dense material (arrowhead). $\times 11,250$

Fig. 4. After fusion of secretory granules, the electron-dense material (arrow) become smaller within the less dense material. $\times 9,300$

Fig. 1-4: Uranyl acetate and lead citrate staining. 

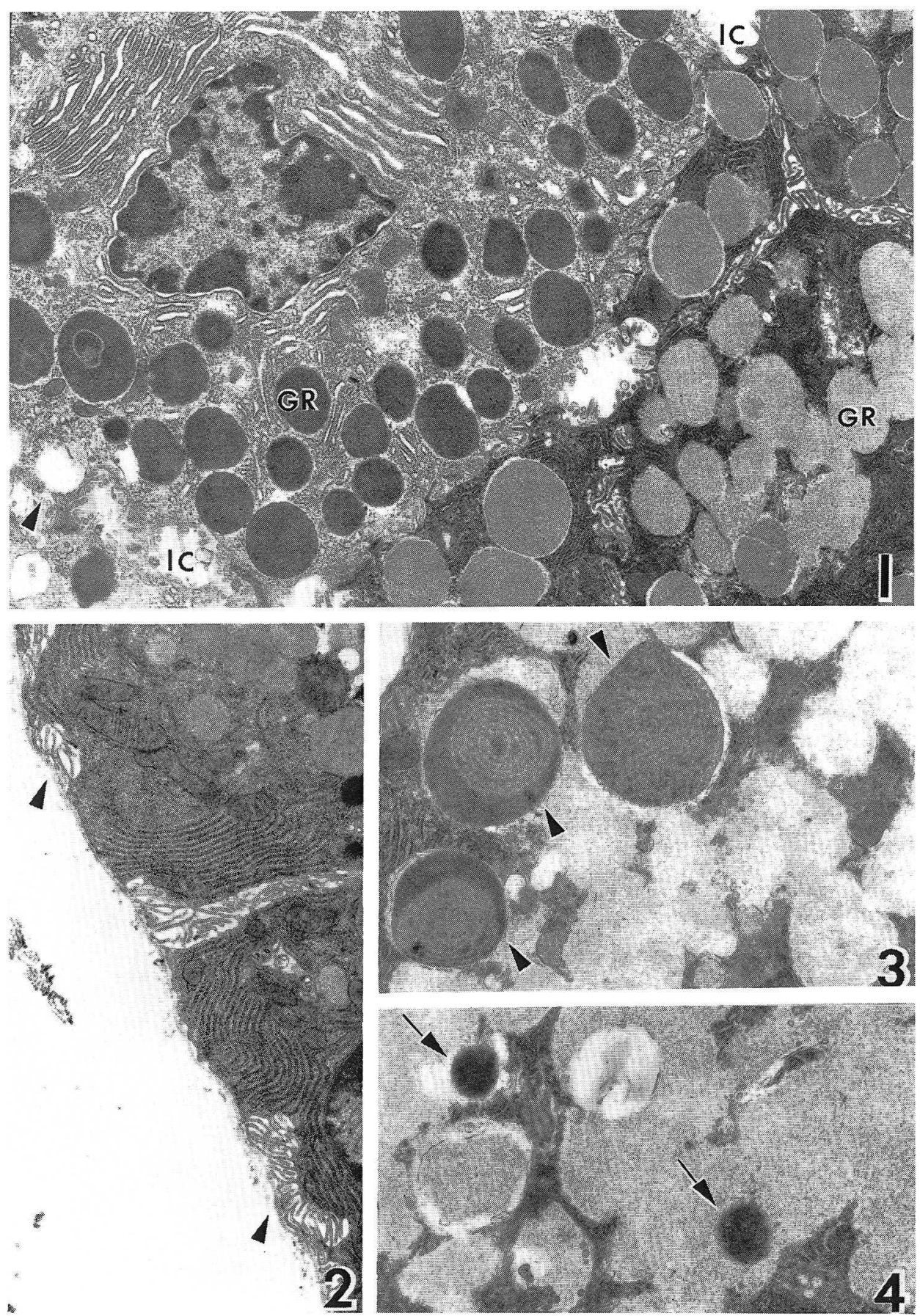

Fig. 1-4. Legends on the opposite page. 

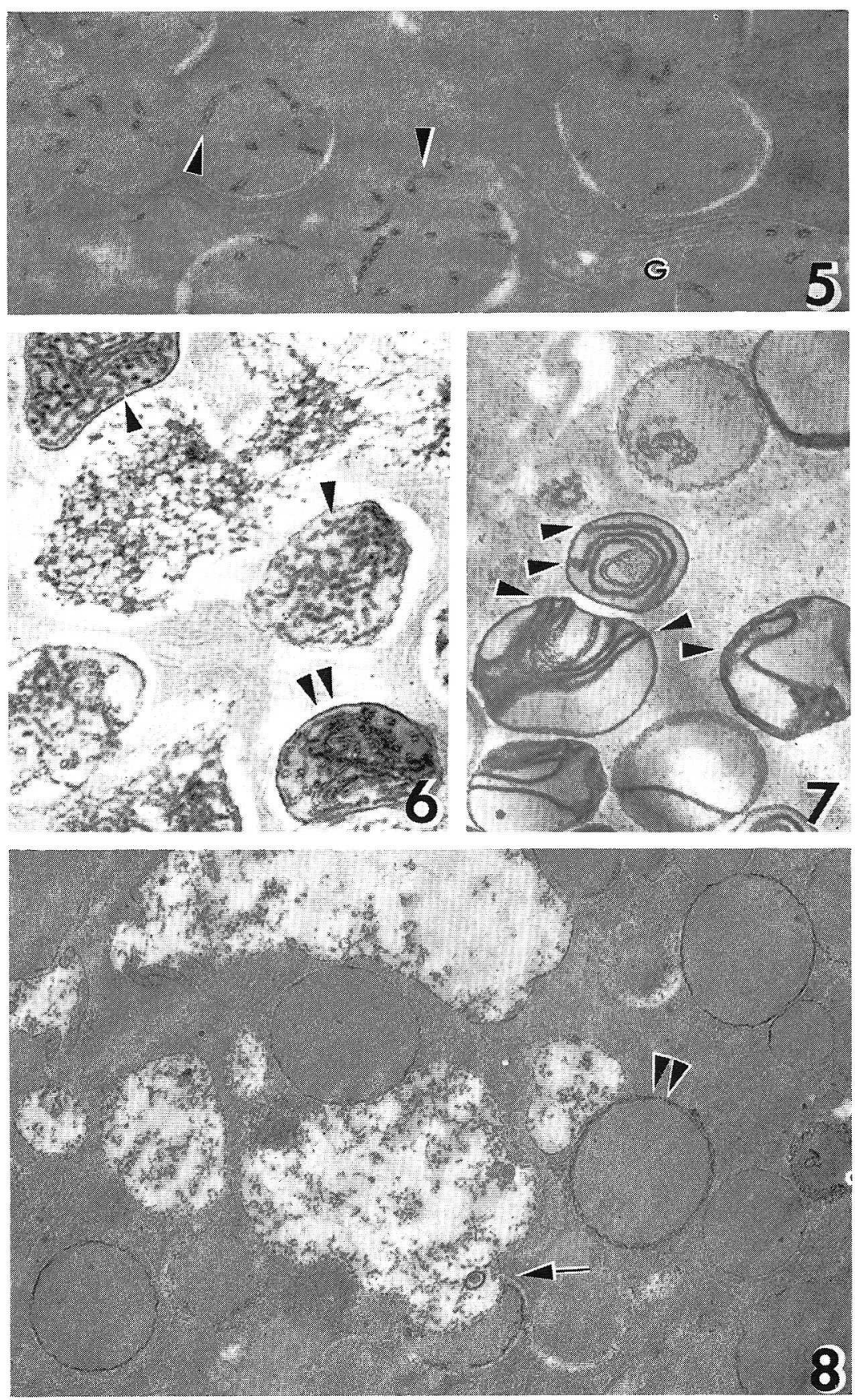

Fig. 5-8. Legends on the opposite page. 
separated from the limiting membrane by a narrow clear rim and often showed thread-like, annual ring-like, or lammellar substructures of lower density in them. PA-TCH-SP staining demonstrated glycoproteins in the secretory granules of acinar cells. From the pattern of glycoprotein localization, the granules could be divided into 4 types: those with heavy deposits on the thread-like substructures (type I) (Fig. 5, 6), on the annual ring-like or lammellar substructures (type II) (Fig. 7), on the narrow clear rim of the granule (type III) (Fig. 8), or on the fine, flocculent material (type IV) (Fig. 6, 8). Fusion of the granules was often observed among type II, III and IV granules (Fig. 6, 8).

The intercalated duct cells were small in size and contained a nucleus which occupied the major part of the cytoplasm. Cell organelles were not well developed and secretory granules were rarely found. On the border between the intercalated ducts and the CGTs, the intercalated duct cells neighbored with differentiated CGT cells and no cells that could be regarded as intermediate between the two cell types were noted (Fig. 9).

The CGT cells were columnar or pyramidal in shape with a nucleus in the basal region. Infoldings of the basal surface were not as well developed as those of the SD cells. The appearance of the cytoplasm of the CGT cells varied considerably according to the phases of their secretory cycle. The secretory granules appeared to be formed from the maturing faces of the Golgi apparatus (Fig. 10). The granules were round and homogenously electron-dense. They accumulated in the apical part of the cytoplasm usually bellow the terminal web, over which an apocrine process was formed. In the region near the terminal web, the granules became irregular in shape and lower in density, with their limiting membrane being unclear (Fig. 11). The matrix of the apocrine processes became more electron-dense than that of the cytoplasm below the terminal web (Fig. 11). The PA-TCH-SP staining showed a small amount of deposits only on the limiting membrane of the granules (Fig. 12). The heaviest deposits occurred on the glycogen particles. No secretory granules were observed within the apocrine processes (Fig. 12,13). After the secretion of their apocrine processes, the CGT cells showed abundant glycogen particles occurring around the mitochondria and newly formed secretory granules in their Golgi regions.

The SD cells were generally columnar in shape with a centrally located nucleus. In the cytoplasm, scattered mitochondria, poorly developed Golgi apparatus, glycogen particles, and irregularly arranged tonofilaments were observed. There were welldeveloped infoldings of the plasma membrane in the basal region of the cell. These

Fig. 5. PA-TCH-SP staining showed electron-dense deposits on the structures (arrowhead) within the granule matrix in the Golgi region. $G$ Golgi lamella. $\times 14,500$

Fig. 6. Well-developed thread-like structures (arrowhead) are observed, and the limiting membrane (double arrowhead) of the granule is also positive to PA-TCH-SP staining $\times 9,900$

Fig. 7. PA-TCH-SP positive lamellar substructures in the acinar cell secretory granules of an acinar cell. The lamellar substructures are closely associated with the limiting membranes of the granules (arrow). $\times 20,750$

Fig. 8. The rim (double arrowhead) of the granular content is PA-TCH-SP positive. Fine flocculent materials within the fused granules and the intercellular canaliculus are also positive to the PA-TCH-SP. Fusion (arrow) of granules is observed. $\times 25,530$

Fig. 5-8: PA-TCH-SP staining. 

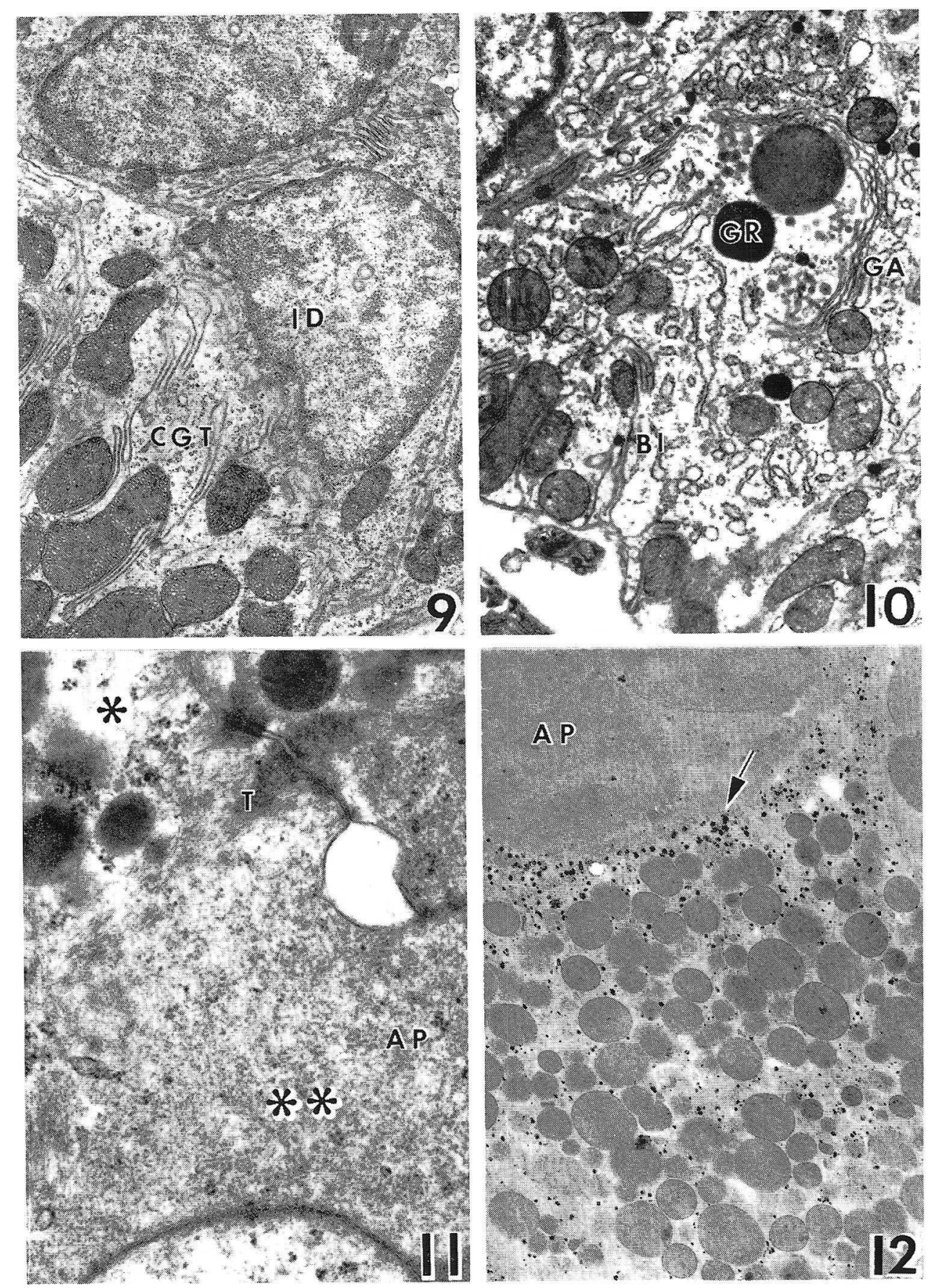

Fig. 9-10. Legends on the opposite page. 


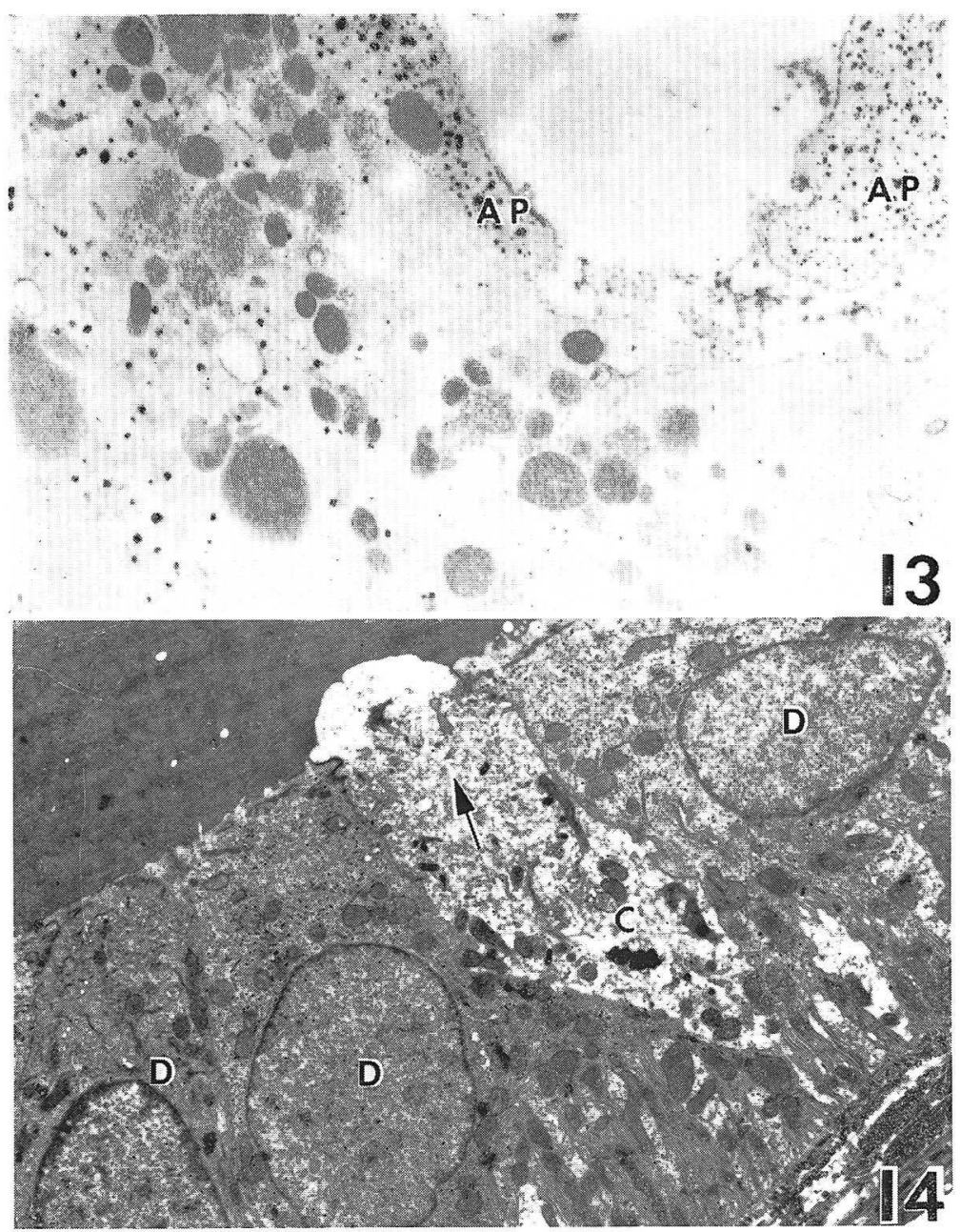

Fig. 13. Heavy deposits are on the glycogen particles in the separating apocrine process $(A P)$ of CGT cells. $\times 21,600$

Fig. 14. A clear cell $(C)$ is distinguished from dark cells $(D)$ in SD. Many vesicles (arrow) are accumulated below the apocrine process. $\times 4,350$

Fig. 13: PA-TCH-SP staining, Fig. 14: Uranyl acetate and lead citrate staining.

Fig. 9. Intercalated duct cells $(I D)$ and cells of convoluted granular tubule (CGT). No transitional forms of cells are observed between the two cell types. $\times 11,200$.

Fig. 10. CGT cells showing high electron-dense granules $(G R)$ in the region of the maturing face of a well-developed Golgi apparatus $(G A)$. Basal infoldings $(B I)$ of the CGT cells are not as well developed as the striated duct cells. $\times 9,240$

Fig. 11. The granules of the CGT cells are located below the terminal web $(T)$. The matrix (double stars) of the apocrine process $(A P)$ is more electron-dense than that (single star) of the cytoplasm below the terminal web. $\times 11,800$

Fig. 12. The matrix of CGT cell granules are not stained with PA-TCH-SP. Their limiting membrane is faintly stained. Heaviest deposits (arrow) are on the glycogen particles. $A P$ apocrine process. $\times 9,600$

Fig. 9-11: Uranyl acetate and lead citrate staining, Fig. 12: PA-TCH-SP staining. 

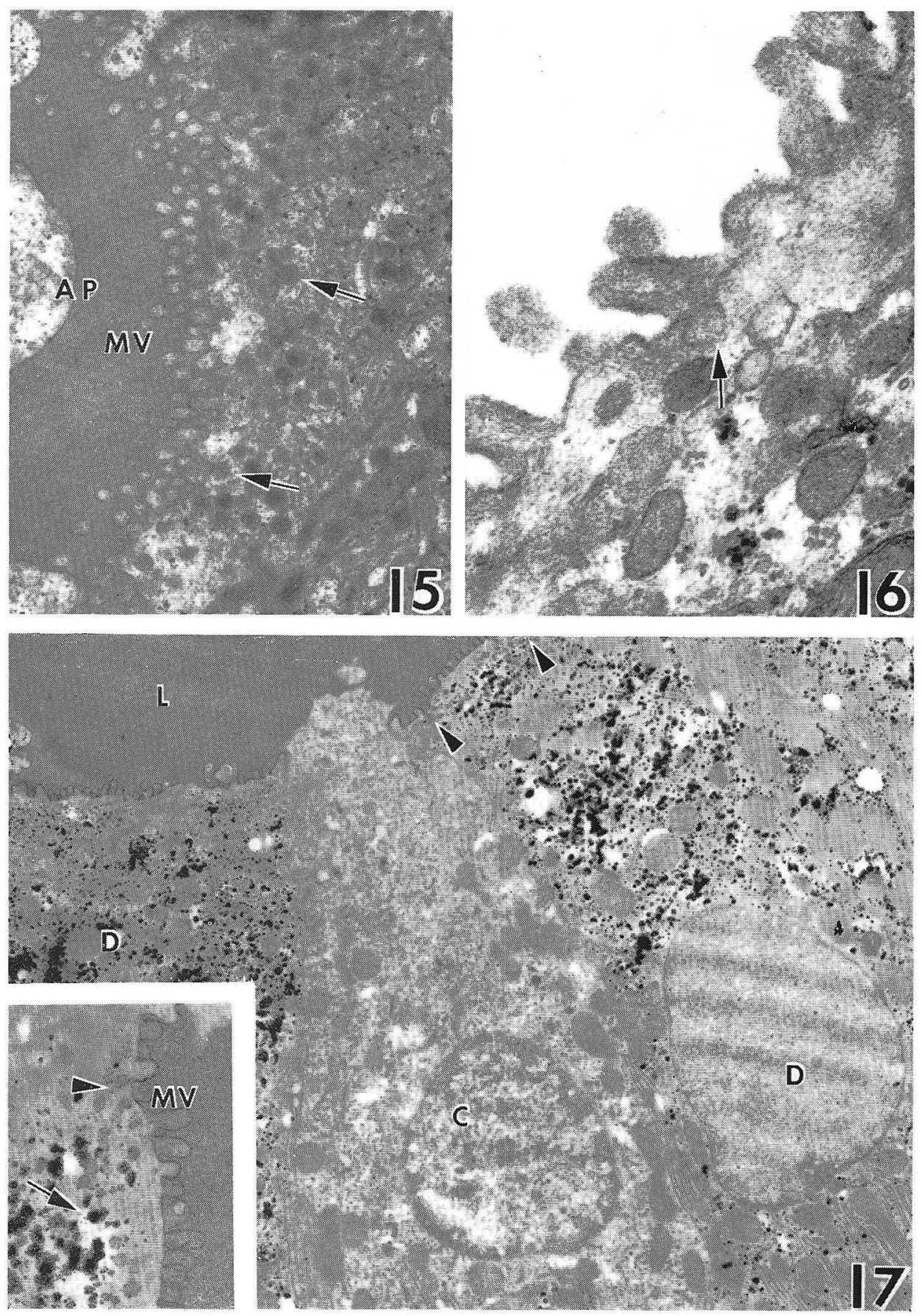

Fig. 15-17. Legends on the opposite page. 
cells could be divided into dark and clear cells (Fig. 14), although there were transitional forms between the two. Small basal cells with poorly developed organelles were observed in the basal region. The dark cells formed the great majority of the SD cells. They had microvilli about $300 \mathrm{~nm}$ in width and $800 \mathrm{~nm}$ in length on their luminal surface and vesicles $100-250 \mathrm{~nm}$ in size filled with a material of moderate electron-density in their apical region above the terminal web (Fig. 15). These vesicles were sometimes associated with the plasma membrane of the luminal surface of the cell (Fig. 16). Smooth endoplasmic reticulum was observed below these vesicles. The contents of the vesicles showed a positive reaction to the PA-TCH-SP staining. In some dark cells with a decreased number of microvilli and distinct terminal webs, their apical cytoplasm formed apocrine processes. The matrix of their cytoplasm being decreased in density, these cells were recognized as clear cells. A number of clear oval vesicles about $100-300 \mathrm{~nm}$ in size were present below the terminal web, and in this region there were a few microtubules (Fig. 19). The apocrine secretory processes contained abundant glycogen particles, but no vesicles or granules. The PATCH-SP staining demonstrated a strong reaction from the glycogen particles, but only a faint reaction in the limiting membrane of the clear vesicles (Fig. 20). In some cells, their luminal surface projected both small apocrine secretory processes and microvilli, representing an intermediate form between dark and clear cells (Fig. 18).

\section{Measurements of the diameters of the CGTs}

The mean diameters of the CGTs were $(57.6 \pm 1.1) \mu \mathrm{m}$ and $(37.4 \pm 0.3) \mu \mathrm{m}$ in males and females respectively. The diameter in male mice was significantly larger than that in female mice (Table 2).

Table 2. Measurements of the diameter of the convoluted granular tubules of submandibular gland of the Japanese wood mouse

\begin{tabular}{lcc}
\hline & o & 申 \\
\hline Number of mice & 8 & 8 \\
Body weight $(\mathrm{g})$ & $36.2 \pm 3.9$ & $42.1 \pm 7.9$ \\
Diameter $(\mu \mathrm{m})$ & $57.6 \pm 1.1$ & $37.4 \pm 0.3$ \\
\hline
\end{tabular}

Fig. 15. A dark cell showing well-developed microvilli $(M V)$. Vesicles $100-250 \mathrm{~nm}$ in size (arrow) with moderate electron-dense contents are present in the apical region of the cell. $\times 22,000$

Fig. 16. High-power view of the apical region of a dark SD cell. A vesicle (arrow) is associated with the plasma membrane of the luminal surface. $\times 40,000$

Fig. 17. A clear cell $(C)$ and dark cells $(D)$ in SD. $\times 4,000$. Inset : Apical region of a SD cell showing vesicles with their PA-TCH-SP positive contents (arrowhead). The heaviest deposits are on the glycogen particles (arrow). $L$ lumen, $M V$ microvilli. $\times 10,000$

Fig. 15 and 16 : Uranyl acetate and lead citrate staining, Fig. 17 : PA-TCH-SP staining. 

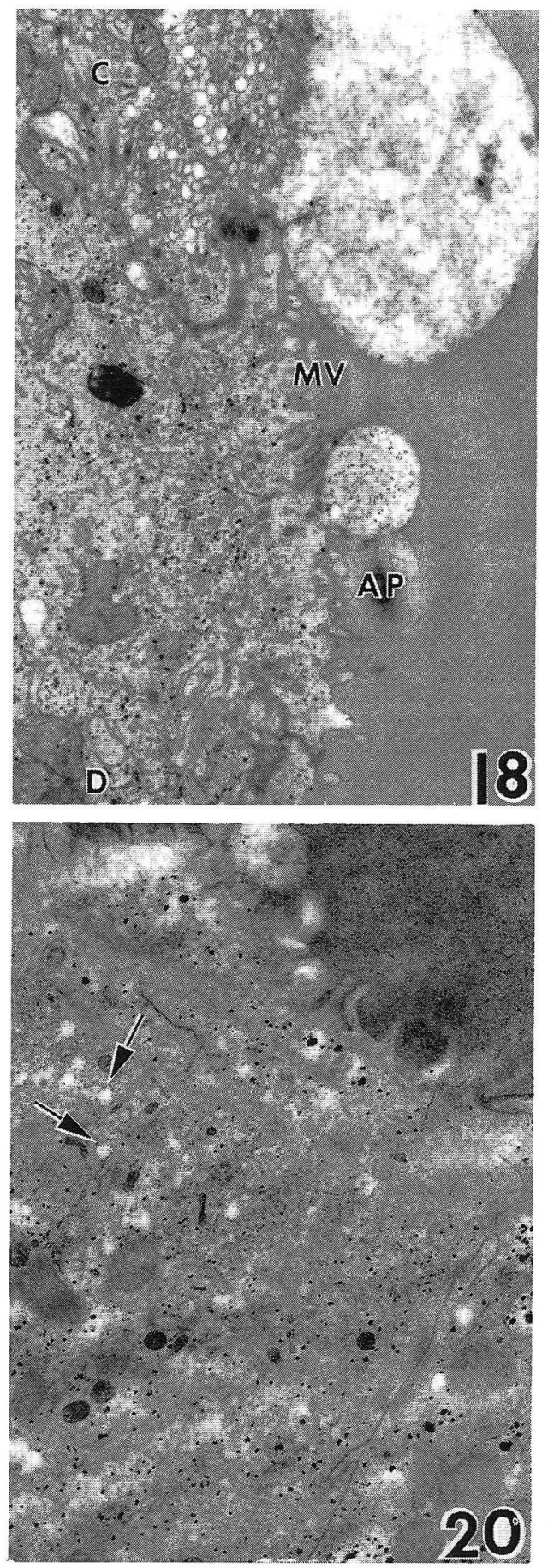

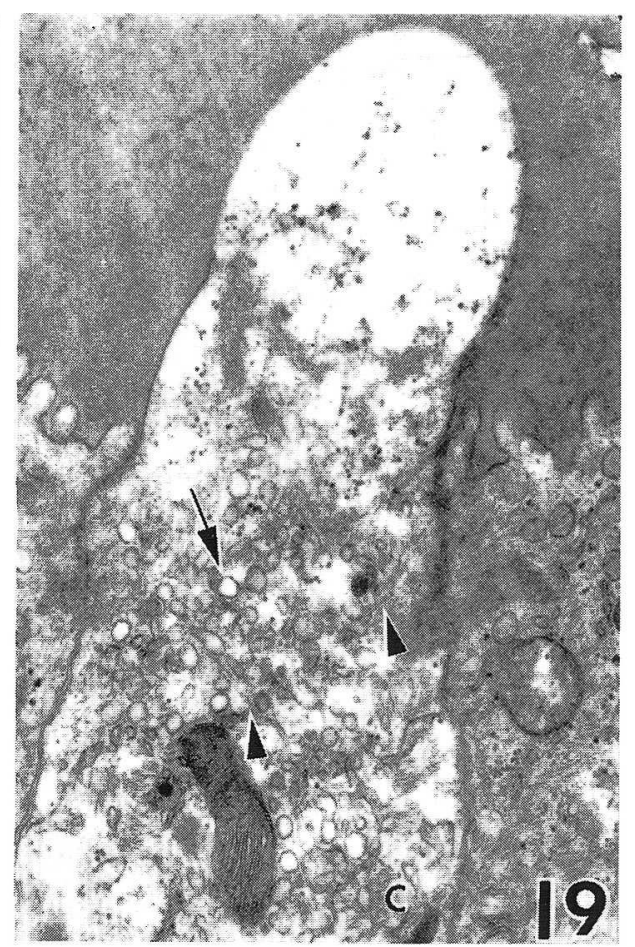

Fig. 18. In some cells their luminal surface had both a small apocrine secretory process $(A P)$ and microvilli $(M V)$ suggesting an intermediate form between the dark $(D)$ and clear cell $(C) . \times 14,300$

Fig. 19. Apical region of a clear SD cell (C) showing microtubules (arrowhead) among the secretory vesicles (arrow) measuring $100-300 \mathrm{~nm}$. $\times 20,160$

Fig. 20. Apical part of SD cells contain vesicles below the apocrine process. The contents of the vesicles are not stained by PA-TCH-SP but their membranes are faintly stained (arrow). $\times 9,000$

Fig. 18 and 19: Uranyl acetate and lead citrate staining, Fig. 20 : PA-TCH-SP staining. 


\section{DISCUSSION}

The present study showed that the acinar cells of the submandibular glands of the Japanese wood mouse consist of only a single type of secretory cell and their secretory granules are seromucous in nature. The interdigitations of small cell processes observed in the acinar cell basal region have also been reported in the human submandibular gland by TANDLER (1962). These structures seem to be efficient and useful for necessary changes in the volume of the secretory cells. The different types (I-IV) of secretory granules may represent stages of maturation. The type I granules with electron-dense contents and glycoprotein positive threadlike substructures were often found in the Golgi regions and were considered to be more immature than the granules of other types. According to YAMAshina and MizuHiRA (1976), the submandibular acinar cells of 1-day-old rats contained immature secretory granules with thread-like substructures similar to those in the Japanese wood mouse. The type IV granules with a fine flocculent material of low electron density were thought to be mature granules readily secreted. The type III granules with a glycoprotein positive rim or the type II granules with annual ring-like substructures were often fused with the type IV granules. Both the type II and III granules are presumed to represent an intermediate stage of the granule maturation.

The granules of the CGT cells contained tyrosine, tryptophan and neutral mucopolysaccharides. It has been reported by ODAJima (1980) that the CGT cells of the Apodemus argenteus TEMmincK submandibular gland showed amylase activity, while the CGT cells of the $A$. a. ainu showed neither amylase nor protease activity when examined by substrate film techniques. This may mean that in the latter the amount of both enzymes may be too small to be detected by the technique used. Electron microscopically demonstrable glycoproteins in the CGT cells were observed only in the limiting membrane of the granule, although the granules were positive to PAS reaction.

The SD cells were divided into dark and clear cells; the former formed the great majority of the SD cells, and the latter possessed apocrine processes. SHACKLEFord and WILBORN (1969) reported the presence of dark cells in the SD duct in the bovine parotid gland. TAMARIN and SREEBNY (1965) reported that dark and basal cells were distinguishable in the rat submandibular gland, and WILBORN and SHACKLEFORD (1969) demonstrated that clear, dark, and basal I and II cells were distinguishable in SD cells in the opossum. The dark cells found in the Japanese wood mouse were similar in cytological appearances to the dark cells of Apodemus argenteus TEMminck (ODAJima, 1980). The vesicles observed in the apical region of the dark SD cells were similar in appearance to those found by RUTBERG (1961) in the SD cells of the mouse submandibular gland. RUTBERG reported that these vesicles increased in number and size $1 \mathrm{hr}$ after an administration of pilocarpine but were not discharged into the lumen, and conjectured that the vesicles were involved in a reabsorption activity of the SD cells. TAMARIN and SREEBNy (1965) observed in the rat that the membrane of such vesicles were continous with the plasma membrane of the luminal surface. SREEBNy and MeYer (1964) compared the duct system of the rat submandibular gland with the proximal convoluted tubule of the kidney. On the basis of their experiments using radioisotopes BuRGEN (1964) suppored that the duct cells of the salivary 
glands were able to transport ions and other substances. NoGUCHI (1967) thought that the parotid epithelia showed absorption activity. Up to now, the vesicles observed in the apical region of the SD cells have been considered to be reabsorption vesicles by many investigators (Rutberg, 1961; TAmarin and Sreebny, 1965; Shackleford and Wilborn, 1970; Riva et al., 1976; Testa-Riva, 1977; Odajima, 1980), although PARKs (1961), LeEson (1969), and HAND (1979) supported the view that the vesicles were involved in a secretory activity of the SD cells. The dark cells observed in the present study had microvilli on their luminal surface and vesicles associated with the surface plasma membrane. The contents of those vesicles showed reaction products with PA-TCH-SP staining. These findings seem to indicate a reabsorption activity of the dark cells from duct contents. The clear cells, on the other hand, had apocrine secretory processes. Their secretory vesicles near the Golgi region of the cell did not show any reaction products with the PA-TCH-SP staining.

In the present study, transitional forms between the dark and clear cells were observed, and some SD cells had both microvilli and apocrine processes on their luminal surface. These findings suggest that the SD cells may have two different functions (secretion and absorption) in the same cell.

Sexual dimorphism of the CGTs of the submandibular glands has been reported by measurements of the diameter of CGTs in the rat (MUDD and WHITE, 1975) by histometric observations on the volume of the CGTs in the mouse (FUKUDA, 1973), and by histochemistry in the hamster (Kronman, 1963a, b). In the Japanese wood mouse, the average diameter of the male CGTs was significantly larger than that of the female, although in Apodemus argenteus TEMminck which is of the same genus, sex differences in the diameter of CGTs were not observed (ODAJIMA, 1980). There are some variations in the sexual dimorphism of the CGTs within the same genus.

Acknowledgement. I am grateful to Prof. T. Hoshino (Department of Oral Anatomy II, Hokkaido University School of Dentistry) for his stimulating discussion.

\section{エリ゙アカネズミ頧下腺の組織化学と微細構造}

小田島美紀代

エゾアカネズミ（Apodemus ainu ainu ToKUDA）成熟此雄の顎下腺の微細構造，分泌顆粒 の性状, 顆粒管直径の性差について調べた。顎下腺は線条部，顆粒性膨大部(顆粒管)，介 在部と終末部とに分けられる。終末部は両性ともに漿粘液性で, 分泌顆粒はグリコプロテ インを含むが，アミラーゼとプロテアーゼ活性を示さなかった．顆粒の成熟に态じたグリ コプロテインの分布と微細構造変化が示された. 顆粒管細胞はトリプトフォン，チロシン と中性粘液多糖類を含有するが，酸性粘液多糖類，プロテアーゼ，アミラーゼやグリコプ ロテインを含まなかった．顆粒内容はアポクリン分泌突起を介して導管内に分泌されてい た. 線条部には暗調細胞と明調細胞がみられ，各々の細胞頂部には小胞がみられた。一方 は再吸収小胞と思われ，他方は分泌小胞と思われた．顆粒管直径の計測から，雄顎下腺の 顆粒管の直径は，雌のそれよりも有意に大きかった。 


\section{REFERENCES}

Brown-Grant, K. and W. Taylor : The relation between structure and concentration of iodide by the submandibular glands of mice and hamsters. J. Morphol. 165: 508-518 (1963).

Burgen, A. S. V.: Kinetic methods for the study of salivary secretions; Their scope and limitations. In: (ed. by) L. M. Sreebny and J. Meyer: Salivary gland and their secretions. Pergamon Press, New York, 1964. (p. 197-215).

Flon, H., R. Gestner, O. G. Mitchell and A. Feldman : Salivary glands of heteromyid rodents, with a summary of the litterature on rodent submandibular gland morphology. J. Morphol. 131: 179-194 (1970).

Fukuda, H.: Histometric observations on the mouse submandibular gland with special reference to the sexual dimorphism (In Japanese). J. Jap. Stomatol. Soc. 22: 12-25 (1973).

Garrett, J. R. and A. Kidd : Effects of nerve stimulation and denervation on secretory material in submandibular striated duct cells of cats, and possible role of these cells in the secretion of salivary kallikrein. Cell Tiss. Res. 161: 71-84 (1975).

Hand, A. R.: Synthesis of secretory and plasma membrane glycoproteins by striated duct cells of rat salivary gland as visualized by autoradiography after ${ }^{3} \mathrm{H}$-fucose injection. Anat. Rec. 195: 317-340 (1979).

Hoshino, K., R. F. Decker, F. Molnar and Y. T. Kim : Hypoglycemic effects of salivary duct ligation upon diabetes mellitus in mice. Arch. oral Biol. 21: 105-111 (1976).

Ichikawa, M. and A. Ichikawa : The fine structure of the parotid gland of the Mongolian gerbil Meriones meridianus. Arch. histol. jap. 38: 1-16 (1975).

Imai, Y. and H. Yoshimura: Water permeability and salt reabsorption in duct system of the submaxillary gland of dog. Jap. J. Physiol. 22: 271-280 (1972).

Kaladelfos, C. G. and J. A. Young : Water and electrolyte excretion in the cat submaxillary gland studies using micropuncture and duct cannulation techniques. Aust. J. exp. Biol. med. Sci. 52: 67-79 (1974).

Kim, Y. T., K. Hoshino, T. Hyodo, H. G. Frisen and L. J. Nahynybida : Hypoglycemic factor in submandibular glands and its etiological relations to diabetes mellitus in mice. Endocrinol. jap. 26: 487-494 (1979).

Kronman, J. H.: Hamster salivary gland sexual dimorphism. 1. Protein histochemical study. J. dent. Res. 42: 123-127 (1963a).

- Hamster salivary gland sexual dimorphism. 2. A histochemical study of acid phosphatase. J. dent. Res. 42: 825-830 (1963b).

Kronman, J. H. and H. H. Chaucey : Hormonal influences upon salivary gland histochemistry. J. dent. Res. 43: 520-527 (1964).

: Testosterone-induced changes in salivary gland histochemistry in the female golden hamster. J. Terap. Pharmacol. 1: 392-405 (1965)

Kronman, J. H. and J. J. Spinale : A histochemical study of testosterone-induced changes in the submandibular and sublingual gland of mice. Amer. J. Anat. 117: 417-431 (1965).

Lacassagne, A.: Mésure de l'action des hormones sexualles sur la glande sous-maxillaire de la souris. C. r. Soc. Biol. 133: 227-229 (1940).

Lawrence, A. M., S. Tan, S. Hojvat and L. Kirsteins : Salivary gland hyperglycemic factor: An extrapancreatic source of glucagon-like material. Science 195: 70-72 (1977).

Leeson, C. R.: The fine structure of the parotid gland of the spider monkey (Ateles paniscus). Acta anat. 72: 133-147 (1969).

Liu, F. T. Y. and H. S. Lin : Effect of progesteron on growth and development of submandibular glands in female rats. J. dent. Res. 48: 943-946 (1969).

Materazzi, G. and L. Vitaioli : Observations on the formation of secretion by the cells of the 'convoluted granular tubules' of the submandibular gland of the rat. J. Anat. 105: 163-170 (1969). 
Mudd, B. D. and S. C. White : Sexual dimorphism in the rat submandibular gland. J. dent. Res. 54: 193 (1975).

Noguchi, T.: Electron microscopic study on the absorption activity of the parotid epithelia. Med. J. Kagoshima Univ. 19 (Suppl.): 691-710 (1967).

Odajima, M. : Ultrastructure, ultracytochemistry and histochemistry of the submandibular gland of the field mouse, Apodemus argenteus Tемміnск. Jap. J. oral Biol. 22: 30-40 (1980).

Parks, H. F.: On the fine structure of the parotid gland of mouse and rat. Amer. J. Anat. 108: 303-329 (1961).

Riva, A., F. Testa-Riva, M. Del Fiacco and M. S. Lantini : Fine structure and cytochemistry of the intralobular ducts of the human parotid gland. J. Anat. 122: 627-640 (1976).

Rutberg, U.: Ultrastructure and secretory mechanism of the parotid gland. Acta odontol. scand. 19 (Suppl. 30): 1-115 (1961).

Schneyer, L. H., J. A. Young and C. A. Schneyer : Salivary secretion of electrolytes. Physiol. Rev. 52: 720-777 (1972).

Scott, B. L. and D. C. Pease : Electron microscopy of the salivary and lacrimal glands of the rat. Amer. J. Anat. 104: 115-161 (1959).

Shackleford, J. and W. H. Wilborn: Ultrastructure of bovine parotid gland. J. Morphol. 127: 453-474 (1969). $276(1970)$.

Shafer, W, G. and J. C. Muhler : Effect of gonadectomy and sex hormones on the structure of the rat salivary glands. J. dent. Res. 32: 262-268 (1953).

Shear, M.: Substrate film techniques for the histochemical demonstration of amylase and protease in salivary glands. J. dent. Res. 51: 368-380 (1972).

Shear, M. and A. G. E. Pearse : A starch substrate film method for the histochemical localization of amylase. Exp. Cell Res. 32: 174-177 (1963).

Sreebny, L. M. and J. Meyer : Hormones, inanition and salivary glands. In: (ed. by) L. M. Sreebny and J. Meyer: Salivary gland and their secretions. Pergamon Press, New York, 1964. (p. 83-102).

Tamarin, A. and L. M. Sreebny : The rat submaxillary gland; correlative study by light and electron microscopy. J. Morphol. 117: 295-352 (1965).

Tandler, B.: Ultrastructure of the human submaxillary gland. I. Architecture and histological relationships of the secretory cells. Amer. J. Anat. 111: 287-307 (1962).

- : Ultrastructure of the human submaxillary gland. II. The base of striated duct cells. J. Ultrastr. Res. 9: 67-75 (1963).

Testa-Riva, F.: Ultrastructure of human submandibular gland. J. submicrosc. Cytol. 9: 251-266 (1977).

Thiéry, J.-P.: Mice en évidence des polysaccharides sur coupes fines en microscopie électronique. J. Microsc. 6: 987-1018 (1967).

Wilborn, W. H. and J. M. Shackleford : The cytology of submandibular glands of the opposum. J. Morphol. 128: 1-34 (1969).

Yamashina, S. and V. Mizuhira: Postnatal develoment of acinar cells in rat submandibular gland as revealed by electron microscopic staining for carbohydrates. Amer. J. Anat. 146: 211-236 (1976).

小田島美紀代

$\overline{\mathbf{T}} 060$ 札幌市北区北13条西 7 丁目

北海道大学䊉学部

口腔解剖学第一講座
Mikiyo Odajima

Department of Oral Anatomy

Hokkaido University School of Dentistry

Kita 13 Nishi 7, Kita-ku

Sapporo, 060 Japan 